\title{
Marketing aspects of sustainable urban development in small towns of the Republic of Tatarstan
}

\author{
Anna Shafigullina*10000-0002-5350-8356], Anastasiia Beloborodova1[0000-0002-7830-0906], \\ Roman Palyakin ${ }^{10000-0003-1265-5648]}, \quad$ Olga Martynova1[0000-0002-3638-9965], and \\ Renat Ahmetshin ${ }^{1[0000-0003-0895-7838] ~}$ \\ ${ }^{1}$ Kazan Federal University, 420008 Kazan, Russia
}

\begin{abstract}
The article describes the concept of sustainable development and forms the criteria for sustainable development of the territory. The sustainability of the territory development should be considered from various angles, including industrial and agricultural development, the level of environmental friendliness, intersectoral and interdimensional interaction, creating the attractiveness of territories. The solution to the problems of territories attractiveness is to be found in the field of territorial marketing. The city as the pinnacle of territorial marketing requires a detailed analysis of the current state and the development of a strategy for further development. The scientific work describes an algorithm for the formation of marketing strategies for urban development. The research provides analysis of small towns development in the Republic of Tatarstan: Almetyevsk, Bolgar, Nizhnekamsk. Developing marketing strategies designed to enhance the attractiveness of small towns are identified as one of the backgrounds for creating comfortable conditions for residents and attracting tourists and professionals to improve the efficiency of the towns' resources. At the same time, it is of vital importance to analyze the internal components of the towns, pull factors for residents and tourists to form the most appropriate marketing strategy for urban development. Small towns, in contrast to megacities, have great creative and cultural potential, which allows them to find new points of attraction on their territory and strengthen the existing tourist and infrastructure facilities.
\end{abstract}

Keywords. Sustainable development, sustainability, sustainable development goals, territory marketing, city marketing strategy.

\section{Introduction}

Following the analysis conducted on the definitions of the term «sustainable development» given by a number of authors, we identified two fundamental requirements: the requirement of environmental sustainability and the requirement of socio-economic sustainability.

\footnotetext{
*Corresponding author: anna88-19@mail.ru
} 
One of the definitions is particularly remarkable, noting that sustainable development is a set of restrictions on human behavior, including restrictions on economic activity (Holden, Linnerud, Banister, 2017).

This definition, in our opinion, does not contradict the above-mentioned conclusions, but it is as simple as possible for the perception of ordinary people. And this is its advantage.

Speaking about the concept of sustainable development, it is worth starting from 17 goals (SDGs) (Fig. 1) adopted at the UN General Assembly by all states on September 25, 2015 within the Resolution 70/1 «Transforming our world: the 2030 Agenda for Sustainable Development».

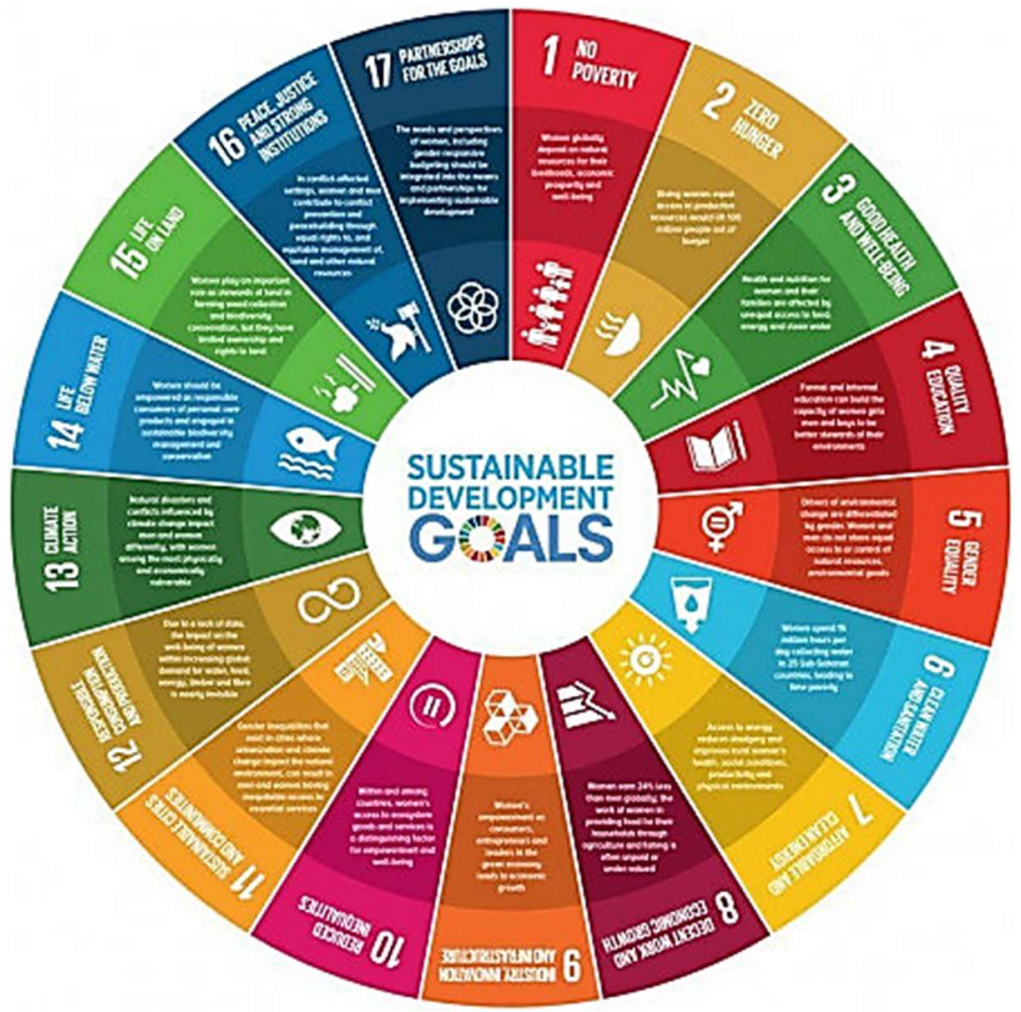

Fig. 1. UN Sustainable Development Goals https://www.un.org/sustainabledevelopment/ru.

Goal eleven focuses on the development of sustainable cities and communities. According to the above-mentioned document, this is understood as a focus on the development of inclusive, safe, resilient, and sustainable cities.

In the Russian Federation, the implementation of SDG 11 «Sustainable cities and settlements» was led by the Ministry of Economic Development.

On June 26, 2020, the first Voluntary National Review of the progress made by the Russian Federation in the achievement of the UN Sustainable Development Goals (SDGs) was published on the UN website.

As part of the implementation of SDG 11, the document published the results in the following areas: increase and reconstruction of residential buildings, automating the accounting of housing and utility services, development of the transport system, planning of public areas (lands), development of single-industry towns, creation of waste recycling and neutralization systems. It should be noted that all implemented activities fit into global trends. So, for example, the development of the transport system is carried out in accordance with 
the requirements described in the article by Wegman, F. «The future of road safety: A worldwide perspective» (Wegman, 2017).

As noted by Holden, E., Linnerud, K., Banister, D. in their work «The Imperatives of Sustainable Development» (Holden, Linnerud, Banister, 2017) and Salvia A.L., Leal Filho, W., Brandli L.L., Griebeler J.S. in the work «Assessing research trends related to Sustainable Development Goals: local and global issues» (Salvia, Leal Filho, Brandli, Griebeler, 2019), the implementation of the SDGs depends on the level of priority that different countries and regions attach to them, and the priorities, in their turn, depend on the list of dominant problems and conditions.

Thus, the targets set out by the UN in the 17 goals of sustainable development are reflected in regional strategies. The article will consider the example of the Republic of Tatarstan, where the goals of sustainable development are integrated in the Strategy of socioeconomic development of the Republic of Tatarstan until 2030. It is also worth noting that in 2019 the Mayor of Kazan headed the UN Advisory Committee of Local Authorities.

Other authors note the complex nature of the SDGs, which, in their opinion, means that progress towards one goal is also linked through complex feedback to other goals (Allen, Metternicht, Wiedmann, 2019).

So, for example, the bulk share of $40 \%$ in the structure of the economy of the Republic of Tatarstan is made up by the industry, therefore, environmental programs of the region and its leading enterprises, programs for the safety of urban spaces, the organization of their territories are priorities within the sustainable development of the region. These issues are addressed in the UN Sustainable Development Goals 11 and 12. Their implementation will have an inevitable effect on the achievement of Goals 6, 7, 8, 9, 13, 14 and 15.

An interesting discussion on industrial ecology and its role in the sustainable development of the region in works of some authors (Mishenin, Koblianska, Medvid, Maistrenko, 2018). The authors come to the conclusion that the achievement of positive results in this direction is impossible on a global scale without considering the regional level as a key one in terms of the development and implementation of modern models of sustainable development.

The problem of territorial development is relevant not only for our region of the Republic of Tatarstan, but for the country as a whole. Analysis of various sources showed that both Russian scientists and scientists from all over the world are engaged in the study of this issue.

Problems of sustainable development are associated with the dynamics of industrial production and the establishment of an appropriate system for assessing indicators. At the same time, the assessment system includes not only industrial production indicators [25, 26], but also criteria for the stability of the economic, environmental and social spheres (Alferova, Shilova, Tretiakova, 2015). It is necessary to mention that there is an interdependence between the sustainability of the environment and the sustainability of the development of industrial production. (Alferova, Ponosova, 2015). At the same time, optimization of environmental risks, in particular environmental safety and environmental risks of the population, has a positive effect on the investment attractiveness of industrial regions (Sugak, 2021).

It is interesting to consider the aspect of the «green worldview», which can be realized through the involvement of educational institutions, business organizations and the media. Maintaining ecological balance is in itself a way to ensure sustainable development of territories. Environmental education can significantly contribute to raising awareness of consumers and producers for sustainable development, as well as serve as a possible measure to prevent public discontent, which, as a result, makes it possible to implement sustainable development of territories (Vidrevich, Pakhalchak, Pervukhina, 2020).

Studies devoted to the territory's development are carried out by various authors and at different scales of geography (at the world level and at the regional one) (Bondarenko, Zakharkina, Syhyda, Saher, 2020; San Eugenio, Ginesta, Compte-Pujol, Frigola-Reig, 2019). At the same time, it is important to perceive the differences in the development of city clusters 
studied using spatio-temporal models and further described with socio-economic trends (Sun, Chen, Xing, Ma, \&Meng, 2021).

Issues related to the sustainable development of rural areas deserve special attention, since the independence and food security of states depends on the level of agricultural development, which is reflected in the indicators of regional development. The authors of this study emphasize that in the Russian Federation 57 regions (50\% of the entire territory of the country) are rural (Glubokova, Kokhanenko, Lukina, 2021).

Scientists from many universities are engaged in research on the development of territories in the Russian Federation. Their research aims to identify the features of sustainable development of the territory of traditional nature use based on the interaction of three sectors of the economy - traditional, industrial and state (Pavlova, Mikhaylova, Malysheva, Samsonova \& Semenova, 2020). It also considers the theoretical aspect of managing sustainable development of territories and analyzes the management of sustainable development on the example of the Sverdlovsk region. (Ulyana, O. (2020). Various authors consider a different set of criteria for sustainable development of territories, one of them is the entrepreneurial activity of the region. As a result of trends in the development of small business within the endogenous approach, the key challenges and problems of the current state of the business sector are determined, their solution would help to accelerate the development of the regions in the Republic. (Shafigullina, Akhmetshin, 2015).

Within the study of sustainable development, it is important to consider institutional factors influencing innovative development and its sustainability. One of the challenges is to determine the possibilities of going beyond the limits of innovative development of micro-, meso- and macrosystems and the key points of institutional impact on innovative development, ensuring its sustainability in the face of uncertainty in the external environment, as well as innovative development can also be considered as a criterion for sustainable development of the region (Shinkevich, Misbakhova, Bashkirtseva, Fedorova, Martynova \& Beloborodova, 2017).

Noteworthy is the importance of considering the effects of interregional and intersectoral interaction, or, i.e., the effects of cluster transfers. There is still no consensus among the authors of scientific works not only on theoretical aspects, but also on methodological issues of the monitoring procedure and tools for assessing development sustainability, especially in the context of the cluster approach (Ferova, Lobkova, Tanenkova, Kozlova, 2019).

Finally, the marketing activity of the regions not only leads to financial and social stability, but also allows attracting new investment funds in the development of territories (Stroev, Plakhova, Sotnikova, Lebedeva \& Skvortsova, 2020).

Thus, the development of a methodology for the formation of marketing territories is a relevant and important aspect of sustainable development of territories.

\section{Materials and methods}

Speaking about the marketing aspects of the territories development within sustainable development,it is necessary to clarify the model of marketing formation of the territory image. In fact, the territorial image is a reflection of the parameters of socio-economic development, the level of infrastructure and provision of all subjects of the territory (residents, non-residents, government agencies and businesses), climatic and natural conditions, cultural value, the level of social protection, the level of improvement.

In return, the image of the territory is an integral part of the marketing strategy for the development of the territory, aimed to improve the presented indicators and increase its competitiveness at the micro, meso and macro levels. At the same time, it is important to understand that the level of the considered territory (city, region, country, cluster, etc.) determines the scale and detail of the ongoing marketing development program. 
Taking the example of a city marketing development project, we propose an algorithm that includes solving the following tasks:

1. Study of the geographical and economic position of the city, description of the main historical and cultural stages of its development.

2. Analysis of the infrastructure and business environment of the city with the identification of the necessary subjects of marketing activities.

3. Description of identity symbols, main amenities, city attractions in order to identify «places of attraction» for various user groups - residents and non-residents of the city.

4. Studying the opinions of the main users - residents and non-residents - about the town and its characteristics to form the values of city users.

5. Aggregated analysis of the internal and external environment in order to identify the strengths and weaknesses of the town, as well as the directions of its development.

6. Description of the town's image, taking into account external and internal factors, opinions of city service users.

7. Revealing the strategic features of the development of the urban environment, aimed at finding potential partners of the town (enterprises and other cities and towns) and determining the prospects for the development of the town to attract additional users and resources.

8. Development of special measures to implement the selected town development strategy.

In terms of strategic development of the city, there are four main marketing strategies image strategy, attractions strategy, personnel strategy and infrastructure strategy (Pankrukhin, 2006).

The main tools of image marketing include communication activities that contribute to the openness of the territory for target users. At the same time, they distinguish a positive, negative, weakly expressed, overly traditional, contradictory, mixed and overly attractive image of the territory. The marketing attractiveness strategy includes tourism infrastructure, transport accessibility and the level of development of public services. This strategy is characterized by the use of public relations concerning the competitive advantages of the territory and the conditions for property obtaining.

Infrastructure marketing is aimed at implementing conditions for the development of operational arguments (road conditions, safety level, development of housing and transport services, educational institutions, amenities) and development arguments (employment, quality of life, business development, investment level).

With regard to development arguments, the Republic of Tatarstan occupies one of the leading places in the Russian Federation. On the example of the entrepreneurial infrastructure, the need for cooperation between government bodies and institutions with entrepreneurial clusters and small businesses has been proved to create sustainable development of the region (Palyakin, Sharafutdinova, Saydasheva, Khametova, 2020).

Finally, with regard to personnel marketing, the development of the territory occurs due to the creation conditions and attracting people of certain professions, working personnel. The implementation of this strategy is possible with the participation of directly governing bodies through their support and motivation of guests, their fight against an oversupply and shortage of jobs.

It is important to note that in terms of the brand of the territory, several dominant measures are distinguished: the functional and economic dimension, the sociocultural dimension, the political dimension, the spiritual and historical dimension, the geographical and ecological dimension, and the emotional dimension.

According to the structure of the Anholt Nation Brands Index, the positions that determine the value of the brand of the territory include the population (reputation of the population, openness, tolerance), management (impartiality and professionalism of the national government), export (image of goods and services produced in the territory), tourism (recreational facilities, natural and man-made landmarks), investment attractiveness and level of immigration (Feinberg, Zhao, 2011). A number of scientists are inclined to expand the list 
of these indicators by an indicator of security, which reflects the level of terrorist threats, respect for human rights and the level of social tension in the region (Sova, Gorte, 2017).

To solve the problem of assessing the sustainable development of territories, the TOPSIS method is used, which overcomes many of the limitations of other approaches. Multi-criteria decision analysis is possible by applying the Technique for Order of Preference by Similarity to Ideal Solution (TOPSIS). The set of criteria that are assumed within the framework of this method can be reduced to the selected areas (aspects) of sustainability. The assessment of sustainable development of territories, according to this approach, is carried out according to the TOPSIS model and includes several directions (criteria): production aspect; social aspect; financial and investment; infrastructural aspect. The proposed instrumental approach was tested on the territory of the Siberian Federal District while assessing the stability of the territory (Lobkova, 2019).

\section{Results and discussion}

In order to visualize the marketing development of the territories, the characteristics of the development of small towns in the Republic of Tatarstan - Bolgar, Almetyevsk and Nizhnekamsk - were studied in the paper. The objects for analysis were not chosen randomly - in 2020, the Republic of Tatarstan celebrated its $100^{\text {th }}$ anniversary in the status of an autonomous republic. The analysis of towns was carried out in several directions: analysis of the external environment using the method of PEST analysis and SWOT analysis of territories, analysis of infrastructure and business environment, creation of the image and brand concepts of these towns with a proposal for measures to develop their marketing strategy.

Table 1. Analysis of the external environment, strengths and weaknesses of small towns of the Republic of Tatarstan.

\begin{tabular}{|c|c|c|c|c|}
\hline Town & $\begin{array}{l}\text { Population size } \\
\text { and density } \\
\text { (in 2020) }\end{array}$ & $\begin{array}{c}\text { Important } \\
\text { environmental factors }\end{array}$ & Strengths & Weak sides \\
\hline 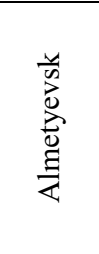 & $\begin{array}{c}157310 \text { people } \\
(1303.65 \\
\left.\text { people } / \mathrm{km}^{2}\right)\end{array}$ & $\begin{array}{l}\text { Labor legislation and } \\
\text { protection of the } \\
\text { population, lifestyle of } \\
\text { the population, degree } \\
\text { of technologies } \\
\text { penetration }\end{array}$ & $\begin{array}{c}\text { High labor } \\
\text { productivity and } \\
\text { resource } \\
\text { availability, } \\
\text { professionalism } \\
\text { of municipal } \\
\text { management }\end{array}$ & $\begin{array}{l}\text { Conditions for } \\
\text { self-organization } \\
\text { of the urban } \\
\text { community have } \\
\text { not been created, } \\
\text { low spending on } \\
\text { the social sphere }\end{array}$ \\
\hline $\begin{array}{l}\text { 营 } \\
\frac{0}{0} \\
0 \\
0\end{array}$ & $\begin{array}{c}8381 \text { people } \\
\left(72 \text { people } / \mathrm{km}^{2}\right)\end{array}$ & $\begin{array}{l}\text { Significant social and } \\
\text { cultural trends, } \\
\text { problems in the } \\
\text { development of small } \\
\text { business }\end{array}$ & $\begin{array}{l}\text { Museum and } \\
\text { historical value, } \\
\text { absence of } \\
\text { harmful } \\
\text { industries } \\
\text { (ecological } \\
\text { value), high } \\
\text { level of } \\
\text { agricultural } \\
\text { development }\end{array}$ & $\begin{array}{c}\text { High } \\
\text { unemployment } \\
\text { rate, low level of } \\
\text { tourism } \\
\text { infrastructure } \\
\text { development }\end{array}$ \\
\hline 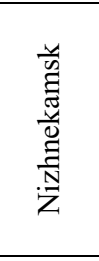 & $\begin{array}{c}238879 \text { people } \\
(2059.3 \\
\left.\text { people } / \mathrm{km}^{2}\right)\end{array}$ & $\begin{array}{l}\text { The level of } \\
\text { innovativeness of } \\
\text { production, migration } \\
\text { policy, external } \\
\text { economic relations }\end{array}$ & $\begin{array}{l}\text { High industrial } \\
\text { production } \\
\text { index and the } \\
\text { position of the } \\
\text { economic } \\
\text { growth driver in } \\
\text { the region }\end{array}$ & $\begin{array}{l}\text { Low level of } \\
\text { scientific } \\
\text { development, } \\
\text { poor } \\
\text { environmental } \\
\text { situation }\end{array}$ \\
\hline
\end{tabular}


The surveyed small towns differ in their positioning. Thus, Almetyevskis considered the oil center of the Republic of Tatarstan. Bolgar, a small city in terms of area and number, is a cultural and spiritual center with the heritage of the Volga Bulgaria. Nizhnekamsk is an industrial city with great production potential.

The towns under study are included in various ratings for assessing sustainable development. Almetyevsk ranks $8^{\text {th }}$ in the ranking of the 150 best Russian cities in terms of the quality of infrastructure for sports and recreation. Bolgar in 2016 ranked $1^{\text {st }}$ among the most popular small towns for tourism. Nizhnekamsk in the official ratings of the quality of life was only in $63^{\text {rd }}$ place out of the 200 largest cities in Russia.

The results of the analysis of the external environment of cities are presented in Table 1.

Based on the results of the analysis, it becomes clear that differences in the development of towns require amendments to their marketing strategies in different directions. Almetyevsk with regard to sustainable development is losing its positions in the field of social development and public infrastructure. In Nizhnekamsk, with a high level of industrial production, there is an outflow of the population due to a low level of personnel development and a high level of pollution. Bolgar, taking into account the high tourist potential, is a town with a small population, mostly employed in agriculture.

At the second stage, the image components of small towns were analyzed. The analysis results are presented in Table 2 .

Table 2. Formation of the image of small towns of the Republic of Tatarstan.

\begin{tabular}{|c|c|c|c|}
\hline Town & $\begin{array}{l}\text { Main points of attraction for } \\
\text { residents }\end{array}$ & Association with the town & Current image \\
\hline Almetyevsk & $\begin{array}{l}\text { Park «City Park named after } \\
60^{\text {th }} \text { Anniversary of Tatarstan } \\
\text { Oil», SEC «Panorama», } \\
\text { Neftyanik Square, Gagarin } \\
\text { Square }\end{array}$ & $\begin{array}{l}\text { The town of «black gold», the } \\
\text { pride of the town }- \text { a cascade } \\
\text { of ponds, a sports town, } \\
\text { beautiful nature }\end{array}$ & Positive \\
\hline Bolgar & $\begin{array}{l}\text { Bulgarian State Historical and } \\
\text { Architectural Museum- } \\
\text { Reserve, Khan's Palace and } \\
\text { White Mosque, Kingdom of } \\
\text { Camels }\end{array}$ & $\begin{array}{l}\text { Eco-friendly city, cultural } \\
\text { contribution, tourist gem, } \\
\text { good festivals }\end{array}$ & Positive \\
\hline Nizhnekamsk & $\begin{array}{l}\text { Park «Family», Ice Palace } \\
\text { «Neftekhimik», Megamall } \\
\text { «Ramus Mall», Nizhnekamsk } \\
\text { Cathedral Mosque }\end{array}$ & $\begin{array}{l}\text { Young and flowery, } \\
\text { financially developed town, } \\
\text { heavy fines, high level of } \\
\text { citizen control }\end{array}$ & Mixed \\
\hline
\end{tabular}

Analyzing the image of cities, one can come to the following conclusions. Almetyevsk has great potential for the development of sports infrastructure and a high level of employment. In addition, it is quite safe here, and the environmental friendliness of transport is developed at a high level - the city is becoming the leader in the number of bike paths. For Bolgar, the main value is the nature and cultural wealth of the territory, which opens up great opportunities for the development of tourism and active recreation. In Nizhnekamsk, the main challenges while forming the positive image are to retain the local population through a higher level of wages and the creation of public areas.

At the final stage, strategic recommendations for the development of towns are given, taking into account their characteristics (Table 3).

Based on the results of the analysis of territorial marketing strategies, the following recommendations are made. Infrastructure marketing will allow Almetyevsk to increase the flow of labour and create comfortable conditions for those people who want to live in a comfortable, beautiful and calm city. In Bolgar, in order to improve the marketing position, it is necessary to develop the tourist infrastructure (hotels and hotel complexes), create leisure 
facilities for residents and improve transport within the town. For Nizhnekamsk, the attractiveness strategy is determined by the need to create favorable conditions for students, create and reconstruct park zones, consolidate the image of a cultural city among young people and form a space for contemporary art.

Table 3. Marketing strategies for small towns of the Republic of Tatarstan.

\begin{tabular}{|c|c|c|c|}
\hline Town & Brand characteristics & $\begin{array}{c}\text { Territory marketing } \\
\text { strategy }\end{array}$ & \multicolumn{1}{c|}{$\begin{array}{c}\text { Activities within the } \\
\text { strategy }\end{array}$} \\
\hline Almetyevsk & $\begin{array}{c}\text { The most comfortable } \\
\text { and progressive town, } \\
\text { «zero» unemployment, } \\
\text { sports town }\end{array}$ & Infrastructure marketing & $\begin{array}{l}\text { Installation of a modern } \\
\text { street lighting system, an } \\
\text { increase in the number of } \\
\text { shopping centers, the } \\
\text { development of business } \\
\text { infrastructure }\end{array}$ \\
\hline Bolgar & $\begin{array}{c}\text { Live history, center of } \\
\text { Islamic culture, } \\
\text { auspicious eco- } \\
\text { friendly city }\end{array}$ & $\begin{array}{c}\text { Infrastructure Marketing } \\
\text { and Attraction } \\
\text { Marketing }\end{array}$ & $\begin{array}{l}\text { Reconstruction of the river } \\
\text { port, opening of hotel } \\
\text { chain, a shopping center } \\
\text { construction }\end{array}$ \\
\hline Nizhnekamsk & $\begin{array}{c}\text { Cultural town, green } \\
\text { town, strong industry, } \\
\text { holy water town }\end{array}$ & $\begin{array}{c}\text { Marketing and Personnel } \\
\text { Marketing }\end{array}$ & $\begin{array}{l}\text { Reconstruction of parks, } \\
\text { improvement of the holy } \\
\text { spring, modernization of } \\
\text { the embankment, } \\
\text { launching a large } \\
\text { technological institute }\end{array}$ \\
\hline
\end{tabular}

\section{Conclusions}

The result of the study of the development of small towns in the Republic of Tatarstan shows that the creation of infrastructural conditions and improvement plays an important role in creating a positive image among target audiences. The quality of life in small towns is determined by the conditions of comfort, safety, the number and quality of recreation areas, the manufacturability of the main infrastructural elements. The need to implement marketing strategies in small towns is explained by the fact that their residents are more interested in creating new conditions for the development of their town and realizing its economic, cultural and creative potential.

In the Materials and methods section, we talked about the application of the TOPSIS method, which was tested in the Siberian Federal District. We believe that the developed integral assessment is applicable to the region of the Republic of Tatarstan. To understand the method, we can consider groups of sustainability indicators: production, social, financial and investment, infrastructural. When selecting indicators and forming sustainability criteria, the approach to the sustainability of the territory as a phenomenon of joint development of all the identified aspects of the socio-economic situation of the subject is taken into account.

Considering the above-mentioned criteria, it is possible to assess the Volga Federal District, including the territory of the Republic of Tatarstan.

In general, we can talk about the positive dynamics of sustainable development of small towns in the Republic of Tatarstan. The implemented improvement programs, the creation of public spaces, the development of transport and social infrastructure make the region a leader in terms of the quality of life in Russia. Undoubtedly, the sustainable development of the region and its towns requires large financial, time and other costs. However, achieving high indicators of sustainable development allows regions and towns to develop their potential at the interregional, state and interstate levels. Taken together, the growth of sustainable development indicators leads to a high quality of life for towns and their inhabitants. 


\section{References}

1. E. Holden, K. Linnerud, D. Banister. The Imperatives of Sustainable Development, Sustainable Development 25 (3), 213-226 (2017). DOI: 10.1002/sd.1647.

2. A.L. Salvia, W. Leal Filho, L.L. Brandli, J.S. Griebeler. Assessing research trends related to Sustainable Development Goals: local and global issues, Journal of Cleaner Production 208, 841-849 (2019). DOI: 10.1016/j.jclepro.2018.09.242.

3. C. Allen, G. Metternicht, T. Wiedmann. Prioritising SDG targets: assessing baselines, gaps and interlinkages, Sustainability Science 14 (2), 421-438 (2019). DOI: 10.1007/s1 1625-018-0596-8.

4. Y. Mishenin, I. Koblianska, V. Medvid, Y. Maistrenko. Sustainable regional development policy formation: Role of industrial ecology and logistics, Entrepreneurship and Sustainability 6 (1), 329-341 (2018). DOI: 0.1007/s11625-018-0596-8.

5. F. Wegman. The future of road safety: A worldwide perspective, IATSS Research $\mathbf{4 0}(2)$, 66-71 (2017). DOI: 10.1016/j.iatssr.2016.05.003.

6. T. Alferova, E. Shilova, E. Tretiakova. Methodical approaches to measuring sustainable development of industrial enterprises, European Research Studies Journal 18 (3), 115-128 (2015). DOI: 10.35808/ersj/459.2-s2.0-84958250000.

7. T. Alferova, E. Ponosova. Sustainable development of industrial enterprises in crisis. Mediterranean Journal of Social Sciences 6 (36), 27-3 (2015). DOI: 10.5901/mjss.2015.v6n3s6p27.2-s2.0-84931056035.

8. E.V. Sugak. Environmental Risk as an Indicator of Sustainable Development of Industrial Regions of Russia, IOP Conference Series: Earth and Environmental Science 666 (6), 062019 (2021). DOI: 10.1088/1755-1315/666/6/062019.2-s2.0-85102767331.

9. M. Vidrevich, G. Pakhalchak, I. Pervukhina. Environmental education as a tool of sustainable development of territories, E3S Web of Conferences 208, 09008 (2020). DOI: $10.1051 / \mathrm{e} 3$ sconf $/ 202020809008$.

10. A.F. Bondarenko, L.S. Zakharkina, L.O. Syhyda, L.Y. Saher. The economic and marketing attractiveness of countries: Measurement and positioning in terms of economic security, International Journal of Sustainable Development and Planning 15 (4), 439-449 (2020). DOI: 10.18280/ijsdp.150404.

11. Z. Sun, X. Chen, H. Xing, H. Ma, Y. Meng. Regional differences in socioeconomic trends: The s patio temporal evolution from individual cities to amega city region over a long time series, PLoS ONE 15, e0244084 (2021). DOI: 10.1371/journal.pone.0244084. 2-s2.0-85098928002.

12. L.G. Glubokova, D.V. Kokhanenko, E.V. Lukina. Indicators of Sustainable Development Goals in the Rural Territories of Russia. IOP Conference Series: Earth and Environmental Science 670 (1), 012059 (2021). DOI: 10.1088/1755-1315/670/1/012059. 2-s2.0-85102389535.

13. J. de San Eugenio, X. Ginesta, M. Compte-Pujol, J. Frigola-Reig. Building a place brand on local assets: The case of the Pla de l'Estany district and its rebranding. Sustainability (Switzerland) 11 (11), 3218 (2019). DOI: 10.3390/su11113218.

14. M.B. Pavlova, V.I. Mikhaylova, M.S. Malysheva, I.V. Samsonova, L.A. Semenova. Sustainable development of territories of traditional environmental management in the conditions of implementation of investment projects, E3S Web of Conferences 161, (2020). DOI: 10.1051/e3sconf/202016102007.

15. O. Ulyana. Management of sustainable development of territories, E3S Web of Conferences 208, (2020). DOI: 10.1051/e3sconf/202020808016.

16. A.V. Shafigullina, R.M. Akhmetshin. Development trends of entrepreneurial activity in the republic of Tatarstan, Mediterranean Journal of Social Sciences 6 (1S3), 495-497 (2015). DOI: 10.5901/mjss.2015.v6n1s3p495. 
17. M.V. Shinkevich, C.A. Misbakhova, S.A. Bashkirtseva, T.A. Fedorova, O.V. Martynova, A.L. Beloborodova. Institutional factors of micro, mezzo and macro systems' innovative development, Journal of Advanced Research in Law and Economics 8 (1), 229-236 (2017). DOI: 10.14505/jarle.v8.1(23).26.

18. I.S. Ferova, E.V. Lobkova, E.N. Tanenkova, S.A. Kozlova. Tools for assessing sustainable development of territories taking into account cluster effects, Journal of Siberian Federal University - Humanities and Social Sciences 12 (4), 600-626 (2019). DOI: $10.17516 / 1997-1370-0412$.

19. E.N. Stroev, L.V. Plakhova, E.A. Sotnikova, O.A. Lebedeva, N.A. Skvortsova. Influence of Marketing of Territories on Increase of Investment Activity, Lecture Notes in Networks and Systems 73, 131-141 (2020). DOI: 10.1007/978-3-030-15160-7_12.2-s2.085070544004.

20. A.P. Pankrukhin. Territory marketing. $2^{\text {nd }}$ ed., Supplemented. - SPb.: Peter, 416 (2006). URL: http://pankrukhin.ru/wordpress/wp-content/uploads/2015/01/Izd-2-pankruhin_a_p marketing_territorii.pdf

21. $\bar{R}$.B. Palyakin, V.A. Saydasheva, N.S. Sharafutdinova, N.G. Khametova. Development of strategic interaction of agents of entrepreneurship infrastructure, Utopia y Praxis Latinoamericana 25 (Extra 12), 245-256 (2020). DOI: 10.5281/zenodo.42801372-s2.085096499354.

22. B.M. Feinberg, X. Zhao. The Anholt - GfK Roper Nation Brands Index ${ }^{S M}$ : Navigating the Changing World, Go F.M., Govers R. (eds) International Place Branding Yearbook (2011). DOI: 10.1057/9780230343320_6.

23. A.N. Sova, O.V. Gorte. Branding territorial entities: a look through the prism of the theoretical concepts of marketing, Bulletin of Voronezh State University. Series: Economics and Management, 92-96 (2017). URL: http:/www.vestnik.vsu.ru/pdf/econ/ 2017/01/2017-01-14.pdf.

24. E.V. Lobkova. Application of the TOPSIS method in solving the problem of assessing the sustainability of the development of territories, Economics and management of the national economy. Economic sciences 3 (172), 47-51 (2019).

25. O.V. Bakhareva, A.I. Romanova, R.S. Safina, I.M. Kursina, T.A. Shindina. Infrastructure in the region: long-term investments of institutional investors in Russia, Journal of Advanced Research in Law and Economics 6 3, 488-503 (2015).

26. A. Romanova and all. Technique of the analysis and assessment of innovative industrial risks at different stages of innovative activity. International Journal of Economics and Financial Issues 6 2, 74-81 (2016). 